\title{
DAMPAK PEMBELAJARAN ONLINE PADA MATA PELAJARAN SOSIOLOGI DI MASA PANDEMI COVID-19 DI SMA 4 PANDEGLANG
}

\author{
${ }^{1}$ Siti Nita Sari, ${ }^{2}$ Haryono \\ ${ }^{1,2}$ Program Studi Pendidikan Sosiologi, Fakultas Keguruan dan Ilmu Pendidikan, Universitas Sultan Ageng Tirtayasa \\ 1e-mail korespondensi: 2290180020@untirta.ac.id, haryono@untirta.ac.id
}

\begin{abstract}
Abstrak : Pandemi Covid-19 telah merubah semua kegiatan diseluruh dunia termasuk dunia pendidikan akibat semakin meluasnya dampak covid-19 kegiatan proses pembelajaran di sekolah diberhentikan sementara dan dialihkan dengan pembelajaran online atau daring, Namun banyak orang tua pro dan kontra terkait pembelajaran secara online. Pembelajaran sosiologi ditengah Covid-19 mengalami perubahan yang seharusnya ada interaksi sosial langsung dalam pemecahan masalah (tatap muka) guru dengan murid berubah menjadi online dikarenakan pembatasan sosial distancing yang mana pembelajaran ini sulit untuk diperaktikan kepada siswa. Tujuan penelitian ini untuk mengetahui bagaimana dampak pembelajaran online pada mata pelajaran sosiologi di SMAN 4 pandeglang. Metode penelitian ini menggunakan metode kualitatif yaitu dengan bentuk wawancara dan observasi. Berdasarkan hasil wawancara yang dilakukan dapat diketahui bahwa pembelajaran daring masih mengalami kendala seperti sebagian siswa tidak memiliki handphone, jaringan internet yang tidak stabil yang berada di daerah-daerah pelosok sera media pembalajaran yang kurang mendukung. Selain itu siswa juga terkadang kualahan dalam mengerjakan tugas yang diberikan oleh guru karena tugas yang diberikan terlalu banyak namun siswa kurang memahami materi pembalajaran.
\end{abstract}

Kata Kunci: Dampak pembelajaran online, Mata Pelajaran Sosiologi, Covid-19

\begin{abstract}
The Covid-19 pandemic has changed all activities around the world including the world of education due to the widespread impact of covid-19 learning process activities in schools have been temporarily suspended and diverted to online or online learning, however, many parents have pros and cons related to online learning. Sociology learning in the midst of Covid-19 has experienced changes where there should be direct social interaction in problem solving (face-to-face) between teachers and students turning online due to social distancing restrictions where this learning is difficult to practice for students. The purpose of this study was to determine the impact of online learning on sociology subjects at SMAN 4 Pandeglang. This research method uses qualitative methods, namely the form of interviews and observations. Based on the results of the interviews conducted, it can be seen that online learning still experiences problems such as some students do not have cellphones, unstable internet networks in remote areas and learning media that are less supportive. In addition, students also sometimes struggle to do the assignments given by the teacher because the assignments given are too many, but students do not understand the learning material.
\end{abstract}

Keywords: Impact of online learning, Sociology Subject, Covid-19.

\section{PENDAHULUAN}

Virus Corona atau Covid-19 merupakan penyakit yang sangat berbahaya sehingga berdampak pada kehidupan di seluruh dunia termasuk indonesia. Menyebarnya virus ini atau di sebut juga sebagai pandemi membuat pemerintah menerapkan kebijakan seperti menerapkan kebijakan Menjaga jarak (social distancing), memakai masker serta selalu mencuci tangan baik sebelum atau sesudah makan dan beraktifitas di luar rumah. 
Volume 12 | Number 1| April |2021, Page 51-58/ E-ISSN: 2715-1247 dan P-ISSN: 2087-84xx

Hal ini di tujukan sebagai upaya mencegah penyebaran covid-19 di lingkungan masyarakat. Selain itu, tidak hanya di lingkugan masyarakat tapi juga di lingkungan pendidikan juga terkena dampaknya dimana seluruh sekolah ataupun perguruan tinggi di berhentikan sementara dalam sistem pembelajaran tatap muka dan di alihkan menjadi sistem pembelajaran online. Berdasarkan surat Edaran Dari Menteri Pendidikan dan Kebudayaan Nomor 36962/MPK.A/HK/2020 tanggal 13 maret 2020 terkait pembelajaran secara daring dan bekerja dari rumah dalam rangka pencegahan Corona Virus Disease (COVID-19) Surat edaran tersebut merupakan respon pendidikan dalam menyikapi pandemi covid-19. Sejak surat edaran dikeluarkan proses pembelajarn di kelas dialihkan pada pembelajaran daring yang bisa kita sebut dengan social from home.

Dengan menerapkan sistem pembelajran online atau pembelajaran daring ini, terkadang menimbulkan Permasalahan yang sering dihadapi oleh guru yaitu ketika guru tersebut tidak dapat memonitoring proses pembelajaran secara langsung. Permasalahan lainpun juga timbul dari adanya sistem pembelajaran secara online ini yaitu akses informasi yang terkendala oleh jaringan sinyal yang mengakibatkan lambatnya informasi yang diberikan guru kepada siswa akibatnya para siswa tersebut terlambat mengumpulkan tugas yang diberikan oleh guru.

Pembelajaran sosiologi di tengah pandemi Covid-19 juga semakin sempit yang mana terhalang oleh ruang dan gerak dengan protokol Physical distancing yang di berlakukan oleh pemerintah. Sehingga proses pembelajran antara pendidik dan peserta didik tidak dapat dilakukan secara langsung sebagaimana mestinya.

Penerapan proses pembelajaran daring ini juga membuat para pendidik berpikir kembali mengenai model dan metode pembelajaran yang akan digunakan selama pembelajaran online atau daring, yang mana awalnya para pendidik sudah menyiapkan strategi untuk mengajar secara offline kemudian harus mengubah metode yang telah disiapkan. Oleh karena itu, sarana yang dapat digunakan sebagai perangkat pembalajaran online yaitu dianataranya seperti whatsapp, aplikasi zoom, gogle from dan aplikasi belajar.
Namun hasil observasi tentang pembelajaran daring selama covid-19 khususnya pada mata pelajaran sosiologi di SMAN 4 Pandeglang masih belum efektif karena masih banyak siswa tidak dapat mengikuti pembelajaran online akibat kurangnya sarana yang mendukung seperti jaringan sinyal, kouta internet, kurangnya peran orang tua dalam membingbing anaknya utuk belajar di rumah serta siswa kurang memahami materi yang di ajarkan oleh guru. Selain itu, dengan adanya pembelajaran online ini perilaku siswa jauh sekali berbeda dengan pembelajaran tatap muka atau offline yang mana seblumnya siswa sangat bersemangat belajar karena bisa berinteraksi langsung dengan teman-teman serta guru disekolah dan seblaiknya dengan adanya pembelajaran online ini siswa cendrung menyendiri. Hal tersebut membuat peneliti ini penting untuk dilakukuan karena dimana guru dipaksa untuk beradaptasi dalam menerapkan proses pembelajaran daring akibat adanya pandemi Covid-19 dan juga untuk mengetahui bagaimana respon para siswa selama melakukan pembelajaran online.

Dalam hal ini peneliti merumuskan masalah sebagai berikut : pertama, bagaimana dampak pembelajaran online pada mata pelajaran sosiologi di massa pandemi Covid19 di SMAN 4 Pandeglang? Kedua, apa saja kendala guru dan siswa dalam melaksanakan proses pembelajaran daring selama masa pandemi covid-19 di SMAN 4 Pandeglang? Tujuan peneliti ini yaitu untuk mengetahui bagaimana dampak pembelajaran online pada mata pelajaran sosiologi yang kurang kondusif ditengah Covid-19 di SMAN 4 pandeglang.

\section{METODE}

Adapun jenis penelitian yang dilakukan pada penelitian ini adalah penelitian kualitatif yang memperoleh data dengan melakukan observasi dan wawancara. Wawancara dan observasi dilakukan kepada guru dan siswa secara langusng.

Subjek penelitian ini adalah siswa kelas XI IPS dengan jumlah 35 orang dan guru sosiologi di SMAN 4 Pandeglang. Observasi yang dilakukan kepada siswa dengan memberikan pertanyaan kepada 4 Responden terkait pembelajaran online saat pandemi yang di rasa masih kurang efektif pada kegiatan belajar mengajar. Selain itu, peneliti juga melakukan wawancara kepada guru sosiologi 
terkait dengan kendala guru selama proses pembelajaran.

\section{HASIL DAN PEMBAHASAN HASIL PENELITIAN}

Penelitian ini menggunakan teknik wawancara dengan 4 orang yang diwawancarai dan diperoleh hasil untuk menjawab pertanyaan tentang dampak pembelajaran jarak jauh selama Covid-19 di SMAN 4 Pandeglang. Berikut adalah hasil wawancara 4 narasumber. Narasumber 1: (1). Bagimana proses pembelajaran siswa selama pandemi? Jawaban respoden: pemebelajaran online tidak efektif (2). Kendala apa yang akan dihadapi siswa dalam PJJ (proses pembelajaran jarak jauh)? Jawaban responden: ponsel, mengirimkan sinyal, (3). Apakah mudah bagi siswa untuk mempelajari materi yang diberikan guru? (4) jawaban responden: tidak menegrti, karena penyampaian tidak jelas. (5).apakah Metode PJJ diterapkan dengan baik dalam proses pemebalajaran? Jawaban narasumber: tidak efektif. Apakah siswa puas dengan kekammpuan guru memberikan informasi dalam pembelajaran jarak jauh? Jawaban responden: sangat puas, karena biasanya di akhir kursus akan dicantumkan deskirpsi vidio dari materi Youtube.

Narasumber 2: (1) Bagaimana proses belajar siswa selama pandemi? Jawaban responden: efeknya buruk. (2). Dalam proses PPJ, kendala apa yang dihadapi siswa? Jawaban responden: saya kurang paham materi yang diajarkan dan kouta cepet habis. (3). Apakah mudah bagi siswa untuk mempelajari materi yang diberikan guru? Jawban yang di wawancarai: Terkadang mereka bisa mengerti, terkadang tidak. (4). Apakah metode PJJ diterapkan dengan baik dalam jawaban yang di wawancarai: kurang tepat. (5) apakah siswa puas dengan kemampuan guru memberikan informasi dalam pemeblajaran jarak jauh? Responden: tidak puas.

Narasumber 3: (1). Bagaimana proses belajar siswa selama pandemi? Jawaban yang di wawancarai : selama proses pembelajaran ini, saya menemui banyak kesulitan. (2). Dalam proses PJJ, kendala apa yang dihadapi siswa? Jawaban yang di wawancarai : kuota dan sinyal yang kadang kurang bersahabat. (3). Apakah mudah bagi siswa untuk mempelajari materi yang diberikan oleh guru? Jawaban yang di wawancarai: tidak karena guru hanya memberikan materi pokok-pokok saja, jadi tidak ada penjelasan secara rinci. (4). Apakah metode PJJ diterapkan dengan baik selama proses pemeblajaran? Jawban yang di wawancarai : tidak (5) . apakah siswa puas dengan kemapuan guru memebrikan informasi dalam pembelajaran jarak jauh? Responden: sangat tidak puas.

Narasumber 4: (1). Bagaimana proses pembelajaran siswa selama pandemi? Jawaban responden: selama pandemi, siswa dapat belajar online atau dengan aplikasi office 365 untuk belajar online(2). Dalam proses PJJ, kendala apa yang dihadapi siswa? Jawaban responden : sinyal tidak bisa membuka materi yang disampaikan guru di aplikasi Office 365 (3). Apakah mudah bagi siswa untuk mempelajari materi yang diberikan oleh guru? Orang yang diwawancarai : insya Allah mudah, karena saya akan memberikan sesederhana mungkin, mudah dipelajari dan menarik minat siswa.(4). Apakah metode PJJ diterapkan dengan baik dalam proses pembelajara? Jawaban orang yang di wawancarai : sebenernya tidak sepenuhnya benar karena dapat menghalangi siswa untuk memperoleh materi secara langsung yang diberikan oleh guru, namun karena sudah ketentuan dan kebijakan pemerintah, maka untuk memutuskan rantai Covid-19 harus kita terapkan dan dipatuhi. (5) apakah siswa puas dengan kemampuan guru dalam memberikan informasi dalam pembelajaran jarak jauh? Jawaban yang di wawancarai; tidak karena siswa meras bosen dengan pemebalajran online.

\section{Dampak Pembelajaran Online Pada Mata Pelajaran Sosiologi di Masa Pandemi Covid-19 di SMA 4 Pandeglang}

Saat ini, negara di dunia sedang menghadapi pandemi Covid-19 semua aktifitas dibatasi untuk mencegah penyebaran virus corona. Wabah virus corona atau Covid19 merupakan virus yang belum jelas bagaimana penularannya. Di duga penularannya dari hewan ke manusia. Kasuskasus ini muncul semua mempunyai riwayat kontak dengan pasar wuhan. Sehingga akhirnya wabah ini menyebar ke seluruh dunia pada tanggal 12 maret 2020, Organisasi Kesehatan dunia (WHO) mengumumkan penyakit yang disebabkan oleh virus corona tipe baru atau Covid-19 sebagai pandemi. 
Volume 12 | Number 1| April |2021, Page 51-58/ E-ISSN: 2715-1247 dan P-ISSN: 2087-84xx

Dampak pandemi Covid-19 yang berdampak pada bidang pendidikan mengharuskan semua elemen mulai dari tingkatan TK,SD,SMP,SMA, Serta Perguruan Tinggi melakukan proses pembelajaran daring. Sehingga para guru atau dosen dituntut untuk berinovasi dalam meciptakan media pembelajaran yang menarik.

Menurut Wina Sanjaya (2017:224) harus didasari beberapa perinsip-prinsip yaitu; (1) tujuan yang tercapai baik bersifat kognitif, afektif dan pisikomotorik karena tidak semua media dapat diterapkan dan cocok dengan pencapaian tujuan pembelajaran yang disusun. (2) harus ada konsep yang jelas yang menunjang efektivitas dan efisiensi pembelajaran, (3) sesuai dengan karakteristik peserta didik untuk memilih keterkaitan melanjutkan secara mandiri. Untuk itu pendidik harus memilih media yang tepat agar proses pembelajaran berjalan dengan menyenangkan dan sampai ke peserta didik.

Seperti yang kita ketahui bersama bahwa pembelajaran online atau daring adalah proses pembelajaran yang disampaikan secara elektronik dengan menggunakan komputer dan jaringan internet untuk membantu peserta didik agar dapat belajar dimana saja dan kapan saja.

Menurut Mayor Polak sosiologi adalah ilmu pengetahuan yang memperoleh masyarakat keseluruhan yakni hubungan manusia dengan manusia, manusia dengan kelompok, baik formal maupun non formal baik statis maupun dinamis.

Pembelajaran sosiologi erat kaitannya dengan masyarakat yang dilihat dari sudut hubungan antara manusia dan proses yang timbul dari hubungan manusia di dalam masyarakat dalam hubungan manuisa terjadi interaksi atau hubungan timbal balik antara manusia dengan sesamanya. Interaksi ini bisa terjadi di lingkungan sekolah, keluarga, dan di lingkungan masyarakat. pada proses pembelajaran yang dilakukan pada mata pelajaran sosiologi ini sering sekali melibatkan permasalahan sosial dalam proses pembelajaran karena pada dasarnya mata pelajaran sosiologi ini lebih cendrung mengaitkan fenomena-fenomena sosial yang terjadi di lingkungan sekitar sebagai kajian bahan belajar. Kehadiran sosial sangat dibutuhkan antara pendidik dan peserta didik yang berkaitan dengan proses sosial di
dalamnya.(Soekanto, 2012:58). Kontak sosial dan komunikasi sosial antara pendidik dengan peserta didik dapat memberikan pengaruh postif dan signifikan untuk meningkatan motivasi belajar pada mata pelajaran sosiologi.

Proses pembelajaran daring yang terjadi di SMAN 4 Pandeglang masih kurang kondusif dikarenakan ada beberapa faktor yang mempengaruhi proses pembelajaran seperti faktor internal dan faktor eksternal. siswa mengalami penurunan minat, motivasi belajar di kelas. metode pembelaaran yang di gunakan oleh guru berbeda dari biasanya tatap muka yang berinteraksi langsung dengan murid sedangkan jika daring guru menggunakan metode lain berupa penerapan aplikasi- aplikasi yang mendukung dalam kegiatan belajar mengajar seperti whatsapp, google meet dan lainnya.

\section{Masalah Belajar Mengajar di Masa Pandemi COVID-19}

Kesulitan dalam melaksanakan Pendidikan Jarak Jauh (PJJ) atau daring (online) yang cenderung dipaksakan karena kondisi pandemi COVID 19 dan guru di SMAN 4 Pandeglang cenderung fokus pada penuntasan pencapaian kurikulum. Keterbatasan waktu untuk proses belajar mengajar sehingga guru tidak dapat memiliki beban jam mengajar sesuai dengan ketentuan. Kurang efektifnya komunikasi dengan orang tua sebagai mitra guru dalam proses belajar mengajar.Orang tua murid tidak semua orang tua/wali dapat menjadi pendamping anak/siswa ketika belajar di rumah (kesibukam orang tua dengan pekerjaan, rumah tangga, dan lain-lain). Keterbatasan kemampuan orang tua/wali dalam memahami pelajaran dan pemberian motivasi yang kuat dalam mendampingi belajar dirumah. Siswa, sulitnya komunikasi belajar siswa yang diakibatkan suasana rumah yang kurang kondusif diperberat dengan penugasan dari para guru yang sangat banyak.

Disisi lain, cendrung semakin tingkat stres yang diakibatkan teralalu lama keharusan isolasi mandiri dan beraktifitas belajar mengajar secara daring dirumah. Oleh karena itu, diperlukan suatu strategi yang efektif dengan proses mengajar secara dring (online) yang inovatif dan efektif.

Inovasi Belajar Mengajar di SMAN 4 Pandeglang 
Volume 12 | Number 1| April |2021, Page 51-58/ E-ISSN: 2715-1247 dan P-ISSN: 2087-84xx

Masalah pendidikan adalah bersifat kompleksitas, sesuai dengan situasi dan kondisi suatu masyarakatnya. Secara sederhana masalah pendidikan dapat dikelompokkan dalam beberapa jenis, antara lain: (1) Masalah Mutu, (2) Masalah pemerataan, (3) Masalah efektif dan Relevansi, (4) Masalah efisiensi (Hasbullah, 2015:249).

Pendekatan-pendekatan dalam inovasi pembelajaraan agar lebih efektif, falam sejarahnya setidaknya dapat dibedakan menjadi tiga tahapan: (1) Periode di mana manusia masih menggantungkan diri pada alam sekitarnya dengan usaha penyesuaian dengan cara coba-coba; (2) Periode dimana manusia telah menemukan adat dan teknik baru yang menyebabkan ketakutan manusia terhadap alam berkurang, namun timbul ketergantungan baru terhadap birokrasi dan spesialisasi; (3) Periode dimana manusia telah mampu mencapai kerjasama berdasar perencanaan menuju perubahan sosial yang didambakan (Hasbullah, 2015:251).

Pada dasarnya manusia memiliki kemampuan tidak saja mampu menyesuaikan dengan lingkungan yakni dengan mengubah dirinya (autoplastic), namun manusia mampu mengubah lingkungannya demi kepentingan pribadinya (alloplastic). Jadi, manusia mampu menciptakan sesuatu yang baru yang sebelumnya tidak ada, manusia juga mampu melakukan dan menciptakan cara-cara baru yang tidak dikenal dan bahkan tidak ada, serta dapat dilaksanakan lebih baik. Dengan inovasi, kreativitas dan usaha yang terus menerus, sehingga dapat menemukan cara-cara baru dan dapat menjadikan sesuatu yang lebih baik di SMAN 4 Pandeglang.

"Problem Solving" Pembaharuan Pendidikan adalah upaya yang lebih diminati dan berkembang di SMAN 4 Pandeglang. Dengan demikian dalam upaya yang dapat ditempuh dalam inovasi pendidikan adalah sebagai berikut: (1) pemerataan dan peningkatan kualitas, dapat melalui, peningkatan kemampuan tenaga pengajar, memperkaya pengalaman dan memperlancar proses belajar, menetapkan nilai sikap dan keterampilan; (2) memperluas layanan pendidikan secara kuantitas, yaitu melalui, pemberian latihan, program kegiatan yang menarik perhatian kegiatan belajar mengajar; (3) meningkatkan keserasian pendidikan dengan pembangunan dengan cara meningkatkan pengetahuan keterampilan dan sikap pada peserta didik; (4) memberikan upaya peningkatan efektifitas dan efisiensi sistem layanan pembelajaran, melalui pemberian ruang kebebasan belajar sesuai dengan minat dan bakat serta kemampuan yang dimiliki setiap siswa; (5) menciptakan layanan sistem informasi pendidikan yang relevan seperti; tersedianya sarana komunikasi dua arah secara timbal balik, tepat, kontinu dan dapat di andalkan serta visible.

\section{Inovasi dalam Teori Pembelajaran di SMAN 4 Pandeglang}

Secara sederhana inovasi diartikan sebagai pembaruan atau pembahasan dengan ditandai adanya hal-hal yang baru di SMAN 4 Pandeglang. Upaya untuk mewujudkan hal-hal yang baru. Upaya untuk mewujudkan hal-hal yang baru tersebut adalah sangat dipengaruhi oleh beberapa hal antara lain dalam upaya pemecahan masalah yang dihadapi seseorang atau kelompok orang.

Dalam hal lain inovasi dimaknai sebagai ide, gagasan, atau objek yang di temui sebagai hal yang baru oleh seseorang atau kelompok orang untuk digunakan, oleh karena itu inovasi adalah merupakan suatu hal atau suatu hasil karya pemikiran yang cemerlang dengan bercirikan hal-hal baru di SMAN 4 Pandeglang.

Inovasi dalam pendidikan misalnya untuk memecahkan masalah-masalah yang dihadapi telah dikemukakan antara lain dengan usaha pemerataan pendidikan, peningkatan mutu, upaya meningkatkan efektifitas dan efisiensi, serta relevansi pendidikan. Dengan demikian, difusi inovasi pendidikan bisa di adaptasi dan dimanfaatkan untuk pemecahan permasalahan dalam konteks judul paper ini, adalah masalah efektifitas dan efisiensi pembelajaran di masa pandemi COVID 19, yang sampai saat ini belum menunjukkan tanda - tanda akan berakhir.

Beberapa contoh inovasi pembelajaran adalah: Program Belajar Jarak Jauh (PJJ) atau daring, pembelajaran kontekstual (contextual learning), model pembelajaran aktif, kreatif, efektif dan menyenangkan (PAKEM) di SMAN 4 Pandeglang. Paradigma Teori Mengajar yang Dapat di Implementasikan di Masa Pandemi Covid19 Perkembangan paradigma secara praktis mengajar menjadi pembelajaran diantaranya telah melahirkan 
beberapa temuan yang sangat revolusioner dalam bidang pendidikan, diantaranya; Temuan mengajar secara kuantum dan belajar secara kuantum, keduanya terlahir dari pendewasaan dalam memahami apa itu "mengajar".

Model "Quantum Learning" pada hakekatnya dapat diilustrasikan sebagai "interaksi-interaksi yang mengubah energi menjadi cahaya". Jadi, pada dasarnya semua kehidupan adalah energi dalam "Quantum Learning" sebagaimana dikembangkan oleh De Porter \& Hernacki (2002:45) "Kemampuan kerja olah lebih di optimalkan, dimana model ini berpandangan terhadap otak atau fungsi yang berbeda-beda seperti: (1) teori batang otak atau reptilia berfungsi untuk fungsi motor sensorik, kelangsungan hidup: "hadapi atau lari"; (2) sistem limbik atau otak mamalia berfungsi untuk perasaan: emosi, memori, bioritmik sistem kekebalan; (3) neokorteks otak berfungsi dalam bentuk berfikir intelektual, penalaran, perilaku yang waras, bahasa dengan tingkat kecerdasan yang tinggi.Inovasi dari mengajar menuju pembelajaran patut dilakukan secara merata. Di semua jenjang pendidikan, salah satu indikator keberhasilan dalam pembelajaran diasumsikan dapat dicapai melalui fusi inovasi terhadap dunia teknologi informasi dan pendidikan diantaranya budaya cepat atau lebih dikenal dengan "Akselerasi Pembelajaran" (accelaraled learning). Sebagaimana dikemukakan oleh Rose da Nicholl (1997:43) bahwa the accelerated learning bertujuan: (1) to actively involve the emotional brain - there by making things more memorable; (2) shyncronise leaf and right brain activity; (3) mobility all eight intelegness so that learning in accessible to everyone and the resources of the whole mind are used.

Lebih lanjut Nicholl (dalam Miradani, Dantes \& Suarni, 2014) bahwa: Accelerated Learning ini memiliki enam langkah yang terdiri atas: (1) motivating your mind (motivasi pemikiran); (2) acquiring the information (memperoleh informasi); (3) searching out the meaning (menyelidiki makna); (4) triggering memory (memicu memori); (5) exhibiting what you know (memamerkan apa yang anda ketahui); (6) reflecting on how you've learned (merefleksikan bagaimana anda belajar).
Pada dasarnya, terdapat beraneka ragam rumusan tentang pengajar, seperti rumusan bahwa pengajaran itu pada hakekatnya adalah adaptasi dari "transfer of knowledge" jadi aliran ini bahwa peserta didik cukup mengandalkan hanya diberi isi pengetahuanpengetahuan saja. Menurut Febianti (2014) dikemukakan bahwa: Pengajaran adalah upaya dalam memberikan rangsangan (stimulus), bimbingan, pengarahan dan motivasi kepada siswa agar terjadi proses belajar di SMAN 4 Pandeglang.

Dengan terwujudnya penyelenggaraan pembelajaran yang dapat mengimplementasikan hasil difusi teknologi informasi daya mempertimbangkan dan kontrak melalui perilaku biologi komunikasi yang dialami oleh para peserta didik baik kondisi sosial yang berkembang diharapkan mampu menghasilkan budaya pembelajaran yang baik. Selanjutnya dengan strategi pembelajaran tertentu peserta didik dapat terhubung dengan baik. Misalnya, dengan pemberian tugas atau latihan, jadi pada hakekatnya kaitan antara belajar dan mengajar adalah upaya seorang guru memberikan "peluang" bagi siswa untuk terjadi proses belajar di SMAN 4 Pandeglang.

Teori mengajar lain yang dapat digunakan pada kondisi khusus seperti pandemic Covid-19 adalah teori mengajar mencari dan menemukan (discovery inquiry), teori belajar tersebut mendorong peserta didik untuk mampu mencari dan menemukan informasi belajar baru untuk menyelesaikan masalah yang dihadapi peserta didik, sebagaimana yang dikemukakan Richard Shuma (1962) teori mengajar yang dikembangkan adalah pemikiran bahwa siswa memiliki kemampuan dan percaya diri sendiri, sehingga mampi menemukan jawaban dan analisa sendiri dan pada akhirnya siswa mampu menjelaskan hasil belajarnya sendiri.

Dalam mempraktekan teori mengajar ini, seorang guru diharapkan mampu mendekati, mengenali, menggali dan mengembangkan potensi-potensi belajar peserta didik. Dasar teori tersebut mengajar menggunakan pendekatan "discovery inquiry" akan lebih efektif dan mendorong peserta didik mandiri dalam belajar dan berfikir tentang sesuatu sehingga peserta didik memiliki pemahaman berdasarkan pola pikir yang dialami. 
Volume 12 | Number 1| April |2021, Page 51-58/ E-ISSN: 2715-1247 dan P-ISSN: 2087-84xx

\section{Kendala Guru dan Siswa Selama Melakukan Proses Pembelajaran Daring Selama Masa Pandemi Covid-19}

Di era pendemi sekarang ini, peran tenaga pendidik sangat menjadi faktor utama dalam proses pemeblajaran karena pada dasarnya tenaga pendidik merupakan tenaga profesional dalam melaksanakan tugas dan kewajiban sebagai tutor dalam proses pembelajaran serta mempunyai peranan penting dalam kehidupan masyarakat.

Selain itu,dalam proses pembelajaran online tenaga pendidik harus bisa kreatif dan inovatif dalam menciptakan media pembelajaran. Akan tetapi tidak bisa dipungkiri proses pembelajaran online ini masih banyak kendala baik kendala dari guru ya sendiri maupun kendala dari siswa.

\section{Kendala Guru}

Proses yang terjadi dalam pembelajaran online ini menjadi masalah besar bagi guru karena dengan adanya pembelajaran daring ini guru sangat sulit untuk meimplementasikan materi kepada siswa dan dengan metode pembelajaran apa yang cocok untuk proses pembelajaran online ini agar siswa tidak merasa bosen selama proses pembelajaran berlangsung. Selain itu, proses pembelajaran daring ini kurang efektif karena ada beberapa alasan siswa seperti tidak memiliki kuota internet, hadphone dan leptop. sehingga guru tidak dapat mengontrol secara langsung.

\section{Kendala siswa}

Pembelajaran jarah jauh atau daring yang dilakukan oleh siswa meimbulkan beberpa kendala bagi siswa dalam proses pembelajaran. Siswa diharuskan belajar di rumah dengan sistem pembelajaran online dengan fasilitas pendukungnya seperti handphone, laptop, kuota internet, dan sinyal. Namun, dalam proses pembelajarannya beberapa siswa mengalami hambatan sinyal dan juga kuota internet yang terbatas memungkinkan siswa tertinggal pelajaran saat kegiatan belajar mengajar berlangsung. Selain itu, siswa juga tidak dapat mengetahui secara akurat informasi-informasi mengenai tugastugas atau yang lainnya. Siswapun cukup sulit dalam memahami materi yang diajarkan karena kurangnya konsentrasi dan cenderung jenuh. Kurangnya peran orangtua dalam membimbing dan mendukung siswa dalam proses pembelajaran membuat siswapun merasa tidak di perhatikan.

\section{SIMPULAN}

Berdasarkan hasil penelitian diatas mengenai dampak pembelajaran online pada mata pelajaran sosiologi di masa pandemi COVID-19 di SMAN 4 Pandeglang. Peneliti dapat mengambil kesimpulan bahwa dalam pelakasanaan pembelajaran online yang dilaksanakan di SMAN 4 Pandeglang Kebijakan penyelenggaraan belajar mengajar secara daring (jaringa online) sebagai akibat adanya dampak negatif pandemi COVID-19 diseluruh institusi pendidikan telah menyebabkan gangguan besar anta lain: Penyelenggaraan belajar mengajar siswa, gangguan dalam evaluasi, kualitas lulusan dalam proses seleksi. Oleh karena itu sekolah dan pemerintah haruslah mengupayakan strategi yang efektif dan efisien agar tujuan dan ketuntasan dalam pembelajaran dapat tercapai dengan baik.

Dalam pemecahan masalah yang kompleks dalam dunia pendidikan yang di perparah adanya pandemi COVID-19 tidak efektif lagi apabila digunakan pendekantan konvensional, oleh karena itu masalah pendidikan kususnya dampak pandemi COVID-19 dalam belajar mengajar diperlukan pendekatan yang inovatif sebagai perspektif baru yang belum dapat diselesaikan secara konvensional.

Inovasi dalam pembelajaran perlu dilaksanakan secara merata pada semua jenjang pendidikan, salah satu indikator dalam pencapaian pembelajaran adalah kreativitas bagaimana merumuskan teori inovasi terhadap teknologi informasi dengan budaya cepat "Akselerasi Pembelajaran".

\section{DAFTAR RUJUKAN}

Cox, C. (1999). Teaching language arts: A student-and response-centered classroom. Des Moines: Allyn and Bacon.

De Porter, B., \& Hernacki, M. (2002). Quantum Learning, Membiasakan Belajar Nyaman dan Meyenangkan. Bandung: Kaifa.

Febianti, Y. N. (2014). Peer Teaching (Tutor Sebaya) Sebagai Metode Pembelajaran Untuk Melatih Siswa Mengajar. Edunomic Jurnal Pendidikan Ekonomi, 2(2), 80-87.

Hasbullah, M. (2015). Kebijakan Pendidikan dalam Perspektif teori, aplikasi dan 
kondisi objektif di Indonesia. Depok: PT Rajagrafindo Persada.

Kementrian Pendidikan dan Kebudayaan, Keputusan Nomor 719/P/2020 Tentang Pedoman Pelaksanaan Kurikulum pada Satuan Pendidikan dalam Kondisi Khusus.

Miradani, N. M. S., Dantes, N., \& Suarni, N. K. (2014). Pengaruh Implementasi Asesmen Autentik Terhadap Kemampuan Berbicara Bahasa Inggris Dengan Kovariabel Kecemasan Pada Siswa Kelas XI SMK PGRI Payangan. Jurnal Penelitian dan Evaluasi Pendidikan Indonesia, 4(1), 1-11.

DEPDIKNAS. (2008). Kamus Besar Bahasa Indonesia. Jakarta: Pusat Bahasa. TPIP FIP-UPI. (2007). Ilmu dan Aplikasi Pendidikan. Bandung: Imtima.
Goos, M. (2019). Publishing for International Impact in Mathematics Education Research Journals. In Leatham K. (ed), Designing, Conducting, and Publishing Quality Research in Mathematics Education (pp. 213-225). Switzerland: Springer, Cham.

Ellsworth, J. (2001). ERIC DIGEST: A Survey of Educational Change Models. Teacher Librarian, 29(2), 2224.

Tesniyadi, Dema. 2018. Pengelolaan Pendidikan. Yogyakarta. Samudra Biru.

Sanjaya, Wina. 2017. Perencanaan Dan Desain Sistem Pembelajaran. Jakarta. Kencana. Buchori, M. (2001). Transformasi Pendidikan. Jakarta: Pustaka Sinar Harapan 